\title{
Hydroxytyrosol and tyrosol sulfate metabolites protect against oxidized cholesterol pro-oxidant effect in Caco-2 human enterocyte-like cells.
}

\author{
Angela Atzeria $^{\text {, }}$, Ricardo Lucas ${ }^{\text {b }}$, Alessandra Incani ${ }^{a}$, Pablo Peñalver ${ }^{c}$, Alberto Zafra-Gómez ${ }^{\text {, }}$ M. Paola \\ Melis $^{a}$, Roberto Pizzala ${ }^{\mathrm{e}}$, Juan C. Morales ${ }^{\mathrm{b}, \mathrm{c}_{*}}$ and Monica Deiana ${ }^{\mathrm{a} *}$ \\ ${ }_{5}$ Received (in $\left.X X X, X X X\right)$ Xth $X X X X X X X X X 20 X X$, Accepted Xth XXXXXXXXX 20XX \\ DOI: 10.1039/b000000x
}

Abstract

The aim of this study was to investigate the ability of sulfate metabolites of hydroxytyrosol (HT) and tyrosol (TYR) to act as antioxidants counteracting the pro-oxidant effect of oxidized cholesterol in 10 intestinal cells. For this purpose, we synthesized sulfate metabolites of HT and TYR using chemical methodology and examined their antioxidant activity in Caco-2 monolayers in comparison with the parent compounds. Exposure to oxidized cholesterol led to ROS production, oxidative damage, as indicated by MDA increase, a decrease of reduced glutathione concentration and an enhancement of glutathione peroxidase activity. All the tested compounds were able to counteract the oxidizing action of oxidized 15 cholesterol; HT and TYR sulfate metabolites showed an efficiency in protecting intestinal cells comparable to that of the parent compounds, strengthening the assumption that the potential beneficial effect of the parent compounds is retained, although extensive metabolisation occurs, being the resulting metabolites able to exert a biological action themselves.

20 Keywords:

sulfate metabolites, oxidative stress, oxidized cholesterol, olive oil phenolic compounds 


\section{Introduction}

Polyphenols present in extra virgin olive oil, the principal fat component of the Mediterranean diet, have been demonstrated to exert many potentially beneficial biological effects due to, at least in part, their ability to protect against oxidative stress mediated damage ${ }^{1-2}$. Hydroxytyrosol (3,4-dihydroxyphenylethanol; HT) and tyrosol (4-hydroxyphenylethanol; TYR) (Fig. 1) are the most biologically active 5 phenolic alcohols present in the oil, where they exist in simple forms or as conjugates (such as oleuropein); they are structurally identical except that HT has an extra hydroxyl group in the meta position.

10<smiles>OCCc1ccc(O)c(O)c1</smiles>

$1(\mathrm{HT})$<smiles>OCCc1ccc(O)cc1</smiles>

2 (TYR)<smiles>O=[R6]Oc1ccc(CCO)cc1O</smiles>

3

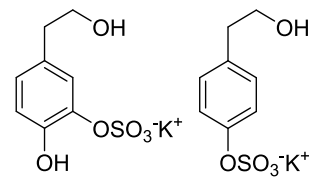

4

5

Fig. 1 Structure of tyrosol (TYR), hydroxytyrosol (HT) and their sulfate metabolites 3-5

The literature on phenolic absorption and metabolism after olive oil ingestion is extensive ${ }^{3-4}$; however, there are still several issues to be 15 clarified. Some complex olive oil polyphenols, among the secoiridoids, are relatively stable under gastric conditions and reach the intestine where they may be directly absorbed or metabolised under absorption ${ }^{5}$; most of the complex olive oil polyphenols however seems to undergo gastrointestinal biotransformation (see de Bock for an excellent review ) ${ }^{6}$, increasing the relative amount of simple phenols, mainly TYR and HT, entering the small and large intestine ${ }^{7}$. At this location the concentration of simple phenols may be quite high, in the high $\mu \mathrm{M}$ range ${ }^{7}$, and they might exert direct protective effects by scavenging reactive species and/or preventing their 20 formation ${ }^{8}$. However, in the process of crossing enterocytes olive oil phenolic compounds are subjected to classical phase I/II biotransformation and to an important first pass metabolism, resulting in almost undetectable concentrations of free HT and TYR in body fluids ${ }^{9}$.

Sulfated and glucuronidated HT and TYR are the predominant metabolites found in human plasma and urine ${ }^{10-11}$, and they have also been shown to concentrate in the intestinal epithelium, since glucuronidation and sulfation are the major pathways of phase II xenobiotic 25 metabolism in the human intestine ${ }^{12-13}$. The potential health benefits of HT, TYR and their derivatives are likely to be due to both parental compounds and their phase I and phase II major metabolites. Glucuronidated metabolites of HT showed a more efficient radical scavenging potency than HT itself ${ }^{11}$ and the ability to protect renal cells ${ }^{14}$ and erythrocytes from oxidative injury was also better than the parent compound ${ }^{15}$. However no data are available up-to-date concerning the antioxidant activity of sulfate metabolites of HT and TYR.

${ }_{30}$ In this study we investigated the possible protective effect of the sulfate metabolites of TYR and HT, in comparison with the parent compounds, against the oxidative damage to intestinal mucosa due to oxidized cholesterol exposure in the human colon adenocarcinoma cell line, Caco-2. After confluence, these cells spontaneously undergo full differentiation in vitro with enterocyte-like features ${ }^{16}$. Caco- 2 cells have been recognized as a suitable model for evaluating the effect of nutrient components, for both normal dietary constituents and toxicants, as oxidizing agents ${ }^{17}$. Large amounts of lipid oxidation products become available, of both exogenous and endogenous origin, 35 at the level of the intestinal mucosa. Dietary oxysterols, derived from cholesterol degradation and oxidation after prolonged storage or cooking of foods rich in cholesterol, have recently been shown to contribute to the onset and further development of oxidative stress and inflammation related intestinal diseases ${ }^{18-19}$. The major oxysterols found in food may contribute to oxidative unbalance of the intestinal epithelium by inducing the generation of reactive oxygen species (ROS) ${ }^{18,20}$. Our purpose was to investigate the ability of sulfate metabolites of HT and TYR to act as antioxidants counteracting the oxysterols induced changes of the cellular redox state and compare 40 them with their parent compounds. For this purpose, we synthesized sulfate metabolites of HT and TYR using chemical methodology and evaluate their uptake/stability in Caco-2 monolayers. Cytotoxicity, production of MDA and ROS species, levels of glutathione and glutathione peroxidase activity were measured to assess the protecting effect of the sulfate metabolites in comparison with the (their) parent olive (remove) phenolic compounds. 


\section{Materials and methods}

\section{Preparation of oxidized cholesterol}

Oxidized cholesterol was prepared essentially as previously described ${ }^{21}$. In brief, samples of $2 \mathrm{ml}$ ( $2 \mathrm{ml}$ aliquots) of pure cholesterol 5 (Sigma Aldrich, St. Louis, MO) solution $(5 \mathrm{mg} / \mathrm{ml}$ in EtOH) were dried down into round-bottomed glass test tubes under vacuum and heated in a $140{ }^{\circ} \mathrm{C}$ oil bath in air for $3 \mathrm{~h}$. The oxidized mixture was separated and analysed by GC-MS for the determination of the relative oxysterols. Briefly, $2 \mu \mathrm{L}$ of the mixture was diluted in $2 \mathrm{~mL}$ of EtOH (1: 1000 dilution). After evaporating under a nitrogen stream, $50 \mu \mathrm{L}$ of pyridine (Sigma Aldrich) and $50 \mu \mathrm{L}$ of N,O-Bis(trimethylsilyl)trifluoroacetamide with trimethylchlorosilane (BSTFA:TMCS; 99: 1) (Sigma Aldrich) were added, mixed and kept at $60{ }^{\circ} \mathrm{C}$ for $45 \mathrm{~min}$. The derivatized sample (1.5 $\left.\mu \mathrm{L}\right)$ was injected 10 into an Agilent (Waldbronn, DE) GC-MS in splitless mode and the column temperature was programmed starting from $70{ }^{\circ} \mathrm{C}$ to $250{ }^{\circ} \mathrm{C}$ $\left(10{ }^{\circ} \mathrm{C} /\right.$ minute), after up to $290{ }^{\circ} \mathrm{C}\left(5^{\circ} \mathrm{C} / \mathrm{min}\right)$ maintained for $10 \mathrm{~min}$, ending at $300{ }^{\circ} \mathrm{C}\left(2{ }^{\circ} \mathrm{C} / \mathrm{min}\right)$ for 5 min (duration about $45 \mathrm{~min}$ total). The helium flow was set at $1.3 \mathrm{~mL} / \mathrm{min}$. The specific parameters of the instrument were as published by Calderon-Santiago et al.

22 Spectra were acquired in scan mode.

GS-MS analysis demonstrated that the mixture contained $58.9 \%$ of cholesterol, $13.5 \%$ of 7 -ketocholesterol, 9.54\% of $7 \beta$ 15 hydroxycholesterol, $5.6 \%$ of $6 \beta$-hydroxycholesterol, $5.87 \%$ of $7 \alpha$-hydroxycholesterol, $4.5 \%$ of cholesta-4,6-dien-3-ol and $2.1 \%$ of 3 keto-4-cholestene.

\section{Synthesis of sulfate metabolites}

\section{General methods.}

HT and HT acetate were obtained from Seprox Biotech (Madrid, Spain), TYR from Sigma Aldrich. All other chemicals obtained from ${ }_{20}$ commercial sources were used without further purification, unless otherwise noted. All reactions were monitored by TLC on precoated Silica-Gel 60 plates F254, and detected by heating with Mostain $\left(500 \mathrm{~mL}\right.$ of $10 \% \mathrm{H}_{2} \mathrm{SO}_{4}, 25 \mathrm{~g}$ of $\left(\mathrm{NH}_{4}\right)_{6} \mathrm{Mo}_{7} \mathrm{O}_{24} \bullet 4 \mathrm{H}_{2} \mathrm{O}$, $1 \mathrm{~g}$ $\left.\mathrm{Ce}\left(\mathrm{SO}_{4}\right)_{2} \bullet 4 \mathrm{H}_{2} \mathrm{O}\right)$. Products were purified by flash chromatography with Merck Silica gel 60 (200-400 mesh). High resolution mass spectra were obtained on an ESI/quadrupole AutoSpec-Q mass spectrometer. NMR spectra were recorded on 300 or $500 \mathrm{MHz}$ spectrometers, at room temperature for solutions in $\mathrm{CDCl}_{3}$, or $\mathrm{D}_{2} \mathrm{O}$. Chemical shifts are referred to the solvent signal. Metabolites were ${ }_{25}$ purified by chromatography with Reverse Phase-C18 Silica gel. Data were processed using manufacturer software, raw data were multiplied by shifted exponential window function prior to Fourier transform, and the baseline was corrected using polynomial fitting.

General procedure for the microwave-assisted $O$-sulfation.

Microwave based sulfation reactions were performed using a microwave synthesizer in sealed reaction vessels. Phenolic derivatives (1.0 equiv), sulfur trioxide-trimethylamine complex, $\mathrm{SO}_{3} \mathrm{NMe}_{3}$, (5 equiv per $\mathrm{OH}$; being this complex previously washed with $\mathrm{H}_{2} \mathrm{O}$, $\mathrm{MeOH}$, 30 and $\mathrm{CH}_{2} \mathrm{Cl}_{2}$ and dried under high vacuum) and a magnetic stirrer bar were placed in a 2-5 mL microwave reaction vial and fitted with a septum, which was then pierced with a needle. The closed vial was then evacuated in high vacuum for $2 \mathrm{~h}$. The mixture was dissolved in dry $\mathrm{CH}_{3} \mathrm{CN}(2.0 \mathrm{~mL})$ and $\mathrm{NEt}_{3}(0.3-1.0 \mathrm{~mL})$ was then added. Reaction mixture was subjected to microwave radiation for $20-40 \mathrm{~min}$ (depending on the compound) at $100{ }^{\circ} \mathrm{C}\left(50-60 \mathrm{~W}\right.$ average power). $\mathrm{MeOH}(1 \mathrm{~mL})$ and $\mathrm{CH}_{2} \mathrm{Cl}_{2}(1 \mathrm{~mL})$ were added, and the solution was layered on the top of a Sephadex LH-20 chromatography column which was eluted with $\mathrm{CH}_{2} \mathrm{Cl}_{2} / \mathrm{MeOH}$ (1:1) to obtain the corresponding 35 triethylammonium salt as a white powder (94-98\% yield).

Triethylamine, 4-(2-(butyryloxy)ethyl)phenyl sulfate salt (7). Tyrosol butyrate $\mathbf{6}^{23-24}(70 \mathrm{mg}, 0.33 \mathrm{mmol})$ and $\mathrm{SO}_{3} \mathrm{NMe}_{3}(233 \mathrm{mg}$, $1.7 \mathrm{mmol}$ ) were submitted under sulfation conditions for $20 \mathrm{~min}$. TLC (Ethyl acetate: MeOH, 10:1) showed the formation of a major product and complete consumption of the initial material. Solvents were removed and the crude extract was purified by sephadex LH-20 $40\left(\mathrm{CH}_{2} \mathrm{Cl}_{2}: \mathrm{MeOH}, 1: 1\right)$ to afford $7(92 \mathrm{mg}, 98 \%)$ as a white powder. ${ }^{1} \mathrm{H}-\mathrm{NMR}\left(300 \mathrm{MHz}, \mathrm{D}_{2} \mathrm{O}\right) \delta$ : $6.72,7.18(2 \mathrm{~d}, 4 \mathrm{H}, \mathrm{J}=8.7 \mathrm{~Hz}, \mathrm{Harom})$, 4.24 (t, 2H, $\left.\mathrm{CH}_{2} \mathrm{OAc}\right), 3.10$ (q, 6H, $\left.-\mathrm{CH}_{2} \mathrm{CH}_{3}\right), 2.88$ (t, 2H, $\left.\mathrm{CH}_{2} \mathrm{Ar}\right), 2.19$ (t, 2H, J = 7.5Hz, $\left.\mathrm{CH}_{2}\right), 1.45\left(\mathrm{~m}, 2 \mathrm{H}, \mathrm{CH}_{2}\right), 1.18(\mathrm{t}, 9 \mathrm{H}$, $\mathrm{CH}_{2} \mathrm{CH}_{3}$ ), $0.74\left(\mathrm{t}, 3 \mathrm{H}, \mathrm{CH}_{3}\right) ;{ }^{13} \mathrm{C}-\mathrm{NMR}\left(125 \mathrm{MHz}, \mathrm{D}_{2} \mathrm{O}\right) \delta: 177.1$ (CO), 150.0, 136.2, 130.3 (2x CHarom), 121.3 (2x CHarom), 65.4 $\left(\mathrm{CH}_{2} \mathrm{OAc}\right), 46.5,36.0\left(\mathrm{CH}_{2} \mathrm{Ar}\right), 34.0,18.3,12.6,8.0\left(\mathrm{CH}_{3}\right)$. ESI-HRMS (ES $)$ Calcd. for $\mathrm{C}_{12} \mathrm{H}_{15} \mathrm{O}_{6} \mathrm{~S}$ (M-H) 287.0589, Found: 287.0594.

${ }_{45}$ Potassium 4-(2-hydroxyethyl)phenyl sulfate (5). Compound 7 (97 $\mathrm{mg}, 0.32 \mathrm{mmol}$ ) was dissolved in $\left.\mathrm{MeOH}_{(10} \mathrm{mL}\right)$ and $\mathrm{K}_{2} \mathrm{CO}_{3}(90$ $\mathrm{mg}, 0.66 \mathrm{mmol}$ ) was added. The reaction mixture was stirred at room temperature for $24 \mathrm{~h}$ and then neutralized with $\mathrm{IR} 120 \mathrm{H}^{+}$resin. Solvent was then removed in vacuum and the crude extract was purified by an RP-C18 column eluted with $\mathrm{H}_{2} \mathrm{O}$ : $\mathrm{MeOH}$ (from 100:0 to 70:30). Fractions containing the desired product were concentrated and freeze-dried affording compound $\mathbf{5}$ as a white solid (68 mg, 94\%). ${ }^{1} \mathrm{H}-\mathrm{NMR}\left(400 \mathrm{MHz}, \mathrm{D}_{2} \mathrm{O}\right) \delta: 7.18,6.86(2 \mathrm{~d}, 4 \mathrm{H}, \mathrm{J}=8.4 \mathrm{~Hz}, \mathrm{Harom}), 3.78,2,78\left(2 \mathrm{t}, 4 \mathrm{H}, \mathrm{J}=6.7 \mathrm{~Hz}, \mathrm{CH}_{2} \mathrm{OH}, \mathrm{CH}_{2} \mathrm{Ar}\right) ;{ }^{13} \mathrm{C}-$ ${ }_{50} \mathrm{NMR}\left(75 \mathrm{MHz}, \mathrm{D}_{2} \mathrm{O}\right) \delta$ : $157(\mathrm{Cq}), 130.3$ (2x CHarom), $129.8(\mathrm{Cq}), 117.1$ (2x CHarom), $63.0\left(\mathrm{CH}_{2} \mathrm{OH}\right), 36.9\left(\mathrm{CH}_{2} \mathrm{Ar}\right) . \mathrm{ESI}^{-\mathrm{HRMS}}\left(\mathrm{ES}^{-}\right)$ Calcd. for $\mathrm{C}_{8} \mathrm{H}_{9} \mathrm{O}_{5} \mathrm{~S}(\mathrm{M}-\mathrm{H}) 217.0171$, Found: 217.0171 .

3-((tert-butyldimethylsilyl)oxy)-4-hydroxyphenethyl acetate (9) and 4-((tert-butyldimethylsilyl)oxy)-3-hydroxyphenethyl acetate (10). To a solution of hydroxytyrosol acetate $\mathbf{8}^{23-24}(223 \mathrm{mg}, 1.13 \mathrm{mmol})$ in DMF (anhydrous, $\left.3 \mathrm{~mL}\right)$ cooled in an ice-water bath under 55 argon were added sequentially tert-butyldimethylsilyl-trifluoromethanesulfonate (TBDMSOTf, $287 \mu \mathrm{L}, 1.25 \mathrm{mmol}, 1.10$ equiv) and diisopropylethylamine ( $\mathrm{i}-\mathrm{Pr}_{2} \mathrm{Net}, 265 \mu \mathrm{L}, 1.52 \mathrm{mmol}, 1.35$ equiv). The mixture was allowed to stir for $30 \mathrm{~min}$ at $0{ }^{\circ} \mathrm{C}$, and TLC (hexane: 


\title{
Cite this: DOI: $10.1039 / \mathrm{c0xx} 00000 x$
}

\author{
www.rsc.org/xxxxxx
}

ARTICLE TYPE

ethyl acetate 3:1) at that point indicated that the reaction was complete. The pale yellow reaction mixture was diluted with EtOAc (100 $\mathrm{mL})$, cast into a separatory funnel, and washed with water $(2 \times 50 \mathrm{~mL})$, brine $(50 \mathrm{~mL})$, and the organic phase was dried $\left(\mathrm{Na}_{2} \mathrm{SO}_{4}\right)$. Filtration and concentration in vacuum afforded the crude extract that was purified by flash column chromatography (hexane:ethyl acetate from 15:1 to 10:1) to afford $\mathbf{9}$ and $\mathbf{1 0}\left(314 \mathrm{mg}, 90 \%\right.$, powder) like a regioisomeric mixture in ratio $\sim 1: 1 .{ }^{1} \mathrm{H} \mathrm{NMR}(400 \mathrm{MHz}$, $\left.{ }_{5} \mathrm{CDCl}_{3}\right) \delta 6.88(\mathrm{~d}, 1 \mathrm{H}, J=8.1 \mathrm{~Hz}$, Harom), $6.83(\mathrm{~s}, 1 \mathrm{H}$, Harom), 6.77 (d, $1 \mathrm{H}, J=8.4 \mathrm{~Hz}$, Harom), $6.73(\mathrm{~d}, 1 \mathrm{H}, J=8.4 \mathrm{~Hz}$, Harom), 6.71(s, 1H, Harom), $6.62\left(\mathrm{~d}, 1 \mathrm{H}, J=8.1 \mathrm{~Hz}\right.$, Harom ), 5.52, $5.45(2 \mathrm{~s}, 2 \mathrm{H}, 2 \mathrm{xOH}), 4.26\left(\mathrm{t}, 2 \mathrm{H}, J=6.7 \mathrm{~Hz}, \mathrm{CH}_{2} \mathrm{OAc}\right), 4.24(\mathrm{t}, 2 \mathrm{H}$, $\left.J=6.4 \mathrm{~Hz}, \mathrm{CH}_{2} \mathrm{OAc}\right), 2.86\left(\mathrm{t}, 2 \mathrm{H}, J=6.7 \mathrm{~Hz}, \mathrm{CH}_{2} \mathrm{Ar}\right), 2,84\left(\mathrm{t}, 2 \mathrm{H}, J=6.4 \mathrm{~Hz}, \mathrm{CH}_{2} \mathrm{Ar}\right), 2.07-2.05\left(2 \mathrm{~s}, 6 \mathrm{H}, \mathrm{CH}_{3} \mathrm{C}=\mathrm{O}\right), 1.05,1.03$ $\left(2 \mathrm{~s}, 18 \mathrm{H}, \mathrm{C}\left(\mathrm{CH}_{3}\right)_{3} \mathrm{x} 2\right), 0.30,0.29\left(2 \mathrm{~s}, 12 \mathrm{H},-\mathrm{Si}\left(\mathrm{CH}_{3}\right) 2 \mathrm{x} 2\right) ;{ }^{13} \mathrm{C}-\mathrm{NMR}\left(125 \mathrm{MHz}, \mathrm{CDCl}_{3}\right) \delta: 171.1,171.0(\mathrm{C}=\mathrm{O}), 147.1,145.9,142.3$, 141.0, 131.8, 129.6 (Cqarom), 122.4, 120.2, 118.6, 117.7, 115.4, 114.8 (CHarom), 65.2, $65.0\left(\mathrm{CH}_{2} \mathrm{OAc}\right), 34.5\left(2 \mathrm{x} \mathrm{CH} \mathrm{C}_{2} \mathrm{Ar}\right), 25.7$

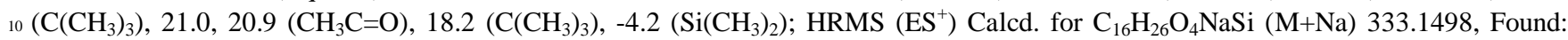
333.1508 .

Triethylamine, 5-(2-acetoxyethyl)-2-((tert-butyldimethylsilyl)oxy)phenyl sulfate salt (11) and triethylamine, 4-(2-acetoxyethyl)-2((tert-butyldimethylsilyl)oxy)phenyl sulfate salt (12). Regioisomeric mixture of compounds $\mathbf{9}$ and $\mathbf{1 0}(157 \mathrm{mg}, 0.506 \mathrm{mmol})$ and ${ }_{15} \mathrm{SO}_{3} \mathrm{NMe}_{3}(351 \mathrm{mg}, 2.52 \mathrm{mmol}$ ) were submitted under sulfation conditions for $2 \times 20 \mathrm{~min}$. TLC (Ethyl acetate:MeOH 10:1) showed the formation of a major product and complete consumption of the starting material. Solvents were removed and crude was purified by sephadex LH-20 in a solvent mixture of $\mathrm{CH}_{2} \mathrm{Cl}_{2}: \mathrm{MeOH} 1: 1$ to afford $\mathbf{1 1}$ and $\mathbf{1 2}(231 \mathrm{mg}, 94 \%$, powder) like a regioisomeric mixture in ratio 1:1. ${ }^{1} \mathrm{H}-\mathrm{NMR}\left(400 \mathrm{MHz}, \mathrm{CDCl}_{3}\right) \delta: 7.50(\mathrm{~d}, 1 \mathrm{H}, \mathrm{J}=7.9 \mathrm{~Hz}$, Harom $), 7.46(\mathrm{~s}, 1 \mathrm{H}$, Harom), $6.82(\mathrm{~d}, 1 \mathrm{H}, \mathrm{J}=8.2 \mathrm{~Hz}$, Harom $), 6.78$ $\left(\mathrm{d}, 1 \mathrm{H}, \mathrm{J}=8.2 \mathrm{~Hz}\right.$, Harom), $6.73\left(\mathrm{~d}, 1 \mathrm{H}, \mathrm{J}=7.9 \mathrm{~Hz}\right.$, Harom), $6.72\left(\mathrm{~s}, 1 \mathrm{H}\right.$, Harom), $4.20\left(\mathrm{t}, 4 \mathrm{H}, \mathrm{J}=7.08 \mathrm{~Hz}, \mathrm{CH}_{2} \mathrm{OAc}\right), 3.10-3.00$ (dq, $\left.2012 \mathrm{H}, \mathrm{CH}_{2} \mathrm{CH}_{3}\right), 2.83\left(\mathrm{t}, 2 \mathrm{H}, \mathrm{J}=7.1 \mathrm{~Hz}, \mathrm{CH}_{2} \mathrm{Ar}\right), 2.82\left(\mathrm{t}, 2 \mathrm{H}, \mathrm{J}=7.05 \mathrm{~Hz}, \mathrm{CH}_{2} \mathrm{Ar}\right), 2.04,2.03\left(2 \mathrm{~s}, 6 \mathrm{H}, \mathrm{CH}_{3} \mathrm{C}=\mathrm{O}\right), 1.26\left(\mathrm{t}, 18 \mathrm{H}, \mathrm{CH}_{2} \mathrm{CH}_{3}\right)$, $1.00,0.99\left(2 \mathrm{~s}, 18 \mathrm{H}, \mathrm{C}\left(\mathrm{CH}_{3}\right)_{3} \times 2\right), 0.21,0.20\left(2 \mathrm{~s}, 12 \mathrm{H},-\mathrm{Si}_{(}\left(\mathrm{CH}_{3}\right)_{2} \mathrm{x} 2\right) ;{ }^{13} \mathrm{C}-\mathrm{NMR}\left(125 \mathrm{MHz}, \mathrm{CDCl}_{3}\right) \delta: 171.0,170.9(\mathrm{C}=\mathrm{O}), 146.8,145.6$, 143.9, 142.8, 134.0, 130.7 (Cqarom), 124.5, 122.4, 121.9, 121.8, 121.6, 121.0 (CHarom), $65.1\left(\mathrm{CH}_{2} \mathrm{OAc}\right), 46.3\left(\mathrm{CH}_{2} \mathrm{CH}_{3}\right), 34.5$,

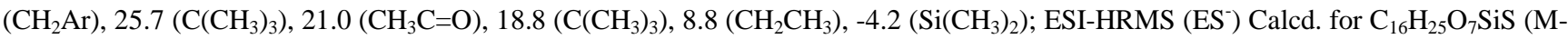
H) 389.1090 , Found: 389.1092 .

25

Potassium 2-hydroxy-4-(2-hydroxyethyl)phenyl sulfate (3) and potassium 2-hydroxy-5-(2-hydroxyethyl)phenyl sulfate (4). Regioisomeric mixture of $\mathbf{1 1}$ and $\mathbf{1 2}(231 \mathrm{mg}, 0.47 \mathrm{mmol})$, potassium fluoride $(\mathrm{KF}, 55 \mathrm{mg}, 0.94 \mathrm{mmol})$ and potassium carbonate $\left(\mathrm{K}_{2} \mathrm{CO}_{3}\right.$, $130 \mathrm{mg}, 0.94 \mathrm{mmol})$ were dissolved in $\mathrm{MeOH}(10 \mathrm{~mL})$. The reaction mixture was stirred at room temperature for $18 \mathrm{~h}$ and solvent was then removed in vacuum. The crude extract was purified by column chromatography with RP-C18 silica gel eluting with $\mathrm{H}_{2} \mathrm{O}: \mathrm{MeOH}$ 30 (from 100:0 to 70:30). Fractions containing the desired product were concentrated and freeze-dried affording compounds 3 and 4 (115 $\mathrm{mg}, 90 \%$, white powder) like a regioisomeric mixture in ratio 1:1. ${ }^{1} \mathrm{H}-\mathrm{NMR}\left(300 \mathrm{MHz}, \mathrm{D}_{2} \mathrm{O}\right) \delta: 7.21(\mathrm{~d}, 2 \mathrm{H}, \mathrm{J}=8.0 \mathrm{~Hz}$, Harom $), 7.17$ (s, 1H, Harom), 6.98 (d, 1H, J = 8.5 Hz, Harom), 6.88 (d, 1H, J = 8.5 Hz, Harom), 6.80 (s, 1H, Harom), 6.70 (d, 1H, J = 8.0 Hz, Harom), 3.76-3.69 (m, 4H, $\mathrm{CH}_{2} \mathrm{OAc}$ ), 2.73-2.70 (m, 4H, $\mathrm{CH}_{2} \mathrm{Ar}$ ); ${ }^{13} \mathrm{C}-\mathrm{NMR}\left(125 \mathrm{MHz}, \mathrm{D}_{2} \mathrm{O}\right)$ ): 149.4, 147.4, 139.0, 138.4, 137.8, 130.7, 127.6, 123.0, 122.6, 120.0, 118.2, 117.6, 62.6, $62.4\left(\mathrm{CH}_{2} \mathrm{OAc}\right), 37.4,36.9\left(\mathrm{CH}_{2} \mathrm{Ar}\right)$. HRMS-ESI (ES) Calcd. for $\mathrm{C}_{8} \mathrm{H}_{9} \mathrm{O}_{6} \mathrm{~S}(\mathrm{M}-\mathrm{H}) 233.0120$, 35 Found: 233.0126.

\section{Cell culture}

Cell culture materials were purchased from Invitrogen (Milano, Italy). Caco-2 cells were obtained from the European Collection of Cell Cultures (ECACC, Salisbury UK) and grown in Dulbecco's modified Eagle's medium (DMEM), supplemented with 2.5\% of heat40 inactivated bovine serum and $100 \mathrm{U} / \mathrm{mL}$ penicillin and $100 \mu \mathrm{g} / \mathrm{mL}$ streptomycin, at $37{ }^{\circ} \mathrm{C}$ under a humidified atmosphere of $95 \%$ air and $5 \% \mathrm{CO}_{2}$. For experimental studies Caco-2 cells, at passage $45-60$, were plated at a density of about $1 \times 10^{5} / \mathrm{mL}$ and used 21 days post seeding

\section{Cytotoxic activity}

The cytotoxic effect caused by the exposure to increasing concentrations of oxidized cholesterol and the protective effect of HT, TYR, 45 and sulfate metabolites was assessed on Caco-2 cells, seeded in 24 -well plates, by the Neutral Red method ${ }^{25}$. Cells were exposed to oxidized cholesterol $(0-175 \mu \mathrm{g} / \mathrm{mL})$ in complete medium and incubated for $24 \mathrm{~h}$. In order to assess the protective effect of the phenolic compounds cells were pretreated with the tested compounds (2,5-10 $\mu \mathrm{M}$ in water solution, $30 \mathrm{~min}$ ) prior to oxidized cholesterol exposure $(100 \mu \mathrm{g} / \mathrm{mL}$ for $24 \mathrm{~h})$. After incubation, the medium was removed; a Neutral Red Solution (Sigma Aldrich) $(0.033 \%$ in medium) was then added to the wells to determine cell viability. After $30 \mathrm{~min}$ of incubation, the Neutral red solution was carefully removed and cells ${ }_{50}$ quickly rinsed with PBS. The incorporated dye was then solubilised in Neutral Red Solubilisation Solution, acetic acid/ethanol /water 
$(1 / 45 / 50, \mathrm{v} / \mathrm{v} / \mathrm{v})$, and the absorbance was measured at $540 \mathrm{~nm}$.

\section{Determination of MDA}

MDA levels were determined in the medium of treated cells by the TBARS test with HPLC quantification, using the method described ${ }_{5}$ by Templar et al. ${ }^{26}$, with some modifications. Briefly, $100 \mu \mathrm{L}$ of $10 \%$ trichloroacetic acid (TCA, Sigma Aldrich) was added to $400 \mu \mathrm{L}$ of the medium, samples were mixed and left at room temperature. After $20 \mathrm{~min}, 200 \mu \mathrm{L}$ of 2 -thiobarbituric acid (TBA, Sigma Aldrich) $(0.6 \%)$ were added; samples were incubated at $90{ }^{\circ} \mathrm{C}$ for $45 \mathrm{~min}$ and then centrifuged at $5000 \mathrm{x} \mathrm{g}$ for $15 \mathrm{~min}$ at $4{ }^{\circ} \mathrm{C}$. Aliquots of the supernatant were injected into an Agilent 1100 HPLC system (Agilent Technologies, Santa Clara, CA) equipped with a diode-array detector (HPLC-DAD) and separation was achieved using a Varian (Middelburg, The Netherlands) Inertsil 5 ODS-2, $150 \times 4.6 \mathrm{~mm}$ 10 column; the mobile phase was a mixture of $\mathrm{KH}_{2} \mathrm{PO}_{4} 50 \mathrm{mM} \mathrm{pH} \mathrm{7/MeOH}(65 / 35, \mathrm{v} / \mathrm{v})$ at a constant flow rate of $1 \mathrm{~mL} / \mathrm{min}$. The formation of the MDA-TBA adduct was revealed measuring its absorbance at $532 \mathrm{~nm}$. A standard curve was prepared using a 1,1,3,3,tetraethoxypropane (TEP, Sigma Aldrich) solution in PBS $(0.05-10 \mu \mathrm{M})$.

\section{ROS production in Caco-2 cells}

Intracellular ROS production was monitored by adding the 2',7'-dichlorodihydrofluorescein diacetate ( $\mathrm{H}_{2}$-DCF-DA, Sigma Aldrich), 15 according to Dinicola et al. ${ }^{27}$, in Caco-2 cells exposed to oxidized cholesterol $(75 \mu \mathrm{g} / \mathrm{mL})$ in complete medium and incubated for $0-180$ min and in cells pretreated with the tested phenolic compounds (5-25 $\mu \mathrm{M}$ in water solution, 30 min), prior to exposure to oxidized cholesterol $(75 \mu \mathrm{g} / \mathrm{mL}$ for $30 \mathrm{~min})$, with some modifications. After incubation the culture medium was replaced with PBS and cells were loaded with $10 \mu \mathrm{M} \mathrm{H}_{2}$-DCF-DA for $30 \mathrm{~min}$. After incubation, PBS and $\mathrm{H}_{2}$-DCF-DA were removed and the cells were washed twice. Increase in cell fluorescence was measured at excitation and emission wavelengths of 490 and $520 \mathrm{~nm}$, respectively, using an Infinite 200 20 auto microplate reader (Tecan, Salzburg, Austria), at $25^{\circ} \mathrm{C}$.

\section{Glutathione (GSH) level and Glutathione peroxidase (GPx) activity}

To assess the changes in the levels of GSH and GPx activity, cells were seeded in plate dishes and exposed to oxidized cholesterol $(75 \mu \mathrm{g} / \mathrm{mL})$ in complete medium for $0-24 \mathrm{~h}$. In order to assess the effect of HT, TYR, HT-S and TYR-S, cells were pretreated with the tested compounds (5-25 $\mu \mathrm{M}$ in water solution, $30 \mathrm{~min}$ ) prior to exposure to oxidized cholesterol $75 \mu \mathrm{g} / \mathrm{mL}$ for $30 \mathrm{~min}$ to determine $\mathrm{GSH}$

${ }_{25}$ level and for $18 \mathrm{~h}$ to measure GPx activity. At the end of incubation time, cells were washed with PBS, and subsequently scraped into $500 \mu \mathrm{L}$ of $5 \%$ metaphosphoric acid. Samples were then sonicated and centrifuged at $10000 \times \mathrm{g}$ for 20 min at $4{ }^{\circ} \mathrm{C}$; supernatants were collected and used to determine GSH level and GPx activity, using Glutathione Assay Kit and Glutathione peroxidase Assay Kit (Cayman Chemical Company, Ann Arbor, USA) according to the manufacturer's instructions.

\section{Statistical analysis}

${ }_{30}$ Data are expressed as means \pm S.D ( $n=12$ for each sample/condition). The statistical evaluation of the results was performed by analysis of variance (ANOVA) followed by a Bonferroni post-hoc test using GraphPad InStat version 3.05 (GraphPad Software, San Diego, CA, USA). 


\section{Results}

Synthesis of HT and TYR sulfate metabolites has been carried out using a protection-deprotection strategy together with the use of microwaves in the critical sulfation step. In the case of TYR, the primary alcohol was acyl- protected using immobilized lipase Novozym $435 \circledR$ and vinyl butyrate in tert-butyl methyl ether (98\% yield) (Scheme 1). Next, microwave-assisted sulfation was performed by 5 treatment with $\mathrm{SO}_{3} \mathrm{NMe}_{3}$ complex and triethylamine in acetonitrile at $100{ }^{\circ} \mathrm{C}$ (98\% yield). Final deprotection with $\mathrm{K}_{2} \mathrm{CO}_{3}$ in $\mathrm{MeOH}$ afforded tyrosol sulfate 5 in good yield (94\%).

10

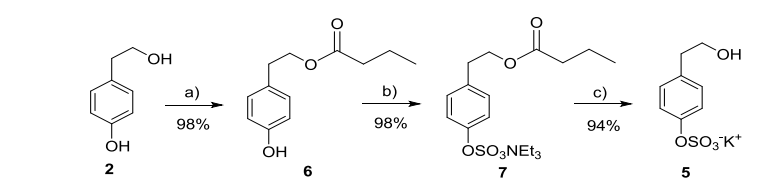

a) Novozym435, vinyl butyrate, TBME; b) $\mathrm{SO}_{3} . \mathrm{NMe}_{3}, \mathrm{TEA}, \mathrm{CH}_{3} \mathrm{CN}, 100^{\circ} \mathrm{C}, 20 \mathrm{~min}, \mathrm{MW}$; c) $\mathrm{K}_{2} \mathrm{CO}_{3}, \mathrm{MeOH}$;

Scheme 1 Preparation of tyrosol sulfate 5

15

Mono-sulfated hydroxytyrosol derivatives $\mathbf{3}$ and $\mathbf{4}$ were prepared as a regioisomeric mixture using a synthetic strategy similar to that of TYR. In this case, hydroxytyrosol acetate $\mathbf{8}$ was mono-silyl protected to avoid disulfated products difficult to separate from the monosulfated derivatives (Scheme 2).

20

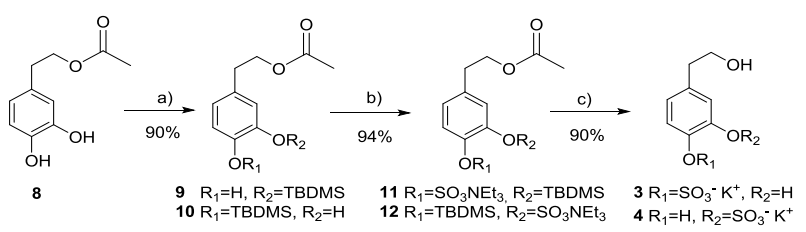

a)TBDMSOTf, DIPEA, $\mathrm{CH}_{2} \mathrm{Cl}_{2}$; b) $\mathrm{SO}_{3} \cdot \mathrm{NMe}_{3}, \mathrm{TEA}, \mathrm{CH}_{3} \mathrm{CN}, 100^{\circ} \mathrm{C}, 20 \mathrm{~min}, \mathrm{MW}$; c) $\mathrm{KF}, \mathrm{K}_{2} \mathrm{CO}_{3}, \mathrm{MeOH}$

Scheme 2 Preparation of hydroxytyrosol sulfate metabolites 3 and 4

Random TBDMS-protection of HT acetate $\mathbf{8}$ and subsequent chromatographic separation afforded a 1:1 regioisomeric mixture of the two possible mono-phenolic compounds 9 and 10. The same sulfation reaction conditions used before were applied to give $94 \%$ yield of a 1:1 30 mixture of isomers 11 and 12. Finally, acetyl and silyl deprotection was carried out in one step using $\mathrm{KF}_{\text {and }} \mathrm{K}_{2} \mathrm{CO}_{3}$ in $\mathrm{MeOH}_{\text {to obtain a }}$ mixture of mono-sulfated hydroxytyrosol derivatives $\mathbf{3}$ and $\mathbf{4}$ (90\% yield).

To investigate the potential protective effect of the HT and TYR sulfate metabolites, in comparison with their parent compounds, against the pro-oxidant effect of oxidized cholesterol in intestinal cells, Caco-2 monolayers were treated for $24 \mathrm{~h}$ with a mixture obtained from the oxidation of cholesterol at $140{ }^{\circ} \mathrm{C}$ for $3 \mathrm{~h}$. In these oxidizing conditions half of the initial cholesterol was turned into oxidation 35 products (reported in the methods section). Treatment with growing concentration of the mixture induced production of MDA and cell death (Fig. 2), indicating the presence of oxidative cell injury. 
$\mathbf{A}$

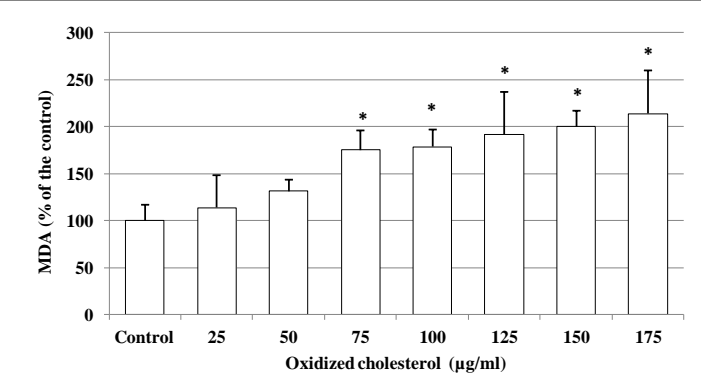

B

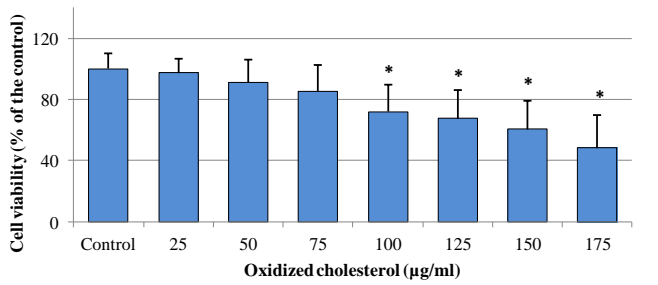

Fig.2 Values of MDA (2A) and cell viability (2B) measured in Caco-2 cells after $24 \mathrm{~h}$ incubation with different concentrations of oxidized cholesterol.

$$
*=\mathrm{p}<0.05 \text { versus control }
$$

Pretreatment with the phenolic compounds significantly inhibited the increase of MDA (Fig. 3) in Caco-2 cells treated with $75 \mu \mathrm{g} / \mathrm{mL}$ of the oxidizing mixture, the highest amount able to induce a significant production of MDA but not cell death. MDA reduction was significant from $2.5 \mu \mathrm{M}$ for HT-S and from $5 \mu \mathrm{M}$ for HT; TYR and its sulfate metabolite exerted the same efficacy starting from $2.5 \mu \mathrm{M}$.

Fig.3 Values of MDA measured in Caco-2 cells after $24 \mathrm{~h}$ incubation with $75 \mu \mathrm{g} / \mathrm{mL}$ oxidized cholesterol and pretreated (30 min) with TYR, HT, HT sulfate metabolites 3-4 (HT-S) and TYR sulfate metabolite 5 (TYR-S) $(2.5-10 \mu \mathrm{M}){ }^{*}=\mathrm{p}<0.05$ versus control, a $=\mathrm{p}<0.05$ versus oxidized cholesterol treated (Ox). 


\section{Journal Name}

\section{Cite this: DOI: $10.1039 / \mathrm{c0xx00000x}$}

Next we examined the ability of HT, TYR and their corresponding sulfate metabolites to protect cells against death in Caco-2 cells treated with $100 \mu \mathrm{g} / \mathrm{mL}$ of oxidized cholesterol, the lowest amount able to induce a significant cell death (Fig. 4). We observed that HT preserved cell viability from the concentration of $5 \mu \mathrm{M}$ whereas HT sulfates 3-4 showed protection at the $10 \mu \mathrm{M}$ concentration. In the case of TYR and its sulfate derivative, both improved cell viability at $10 \mu \mathrm{M}$ concentration.

5

10

15

20

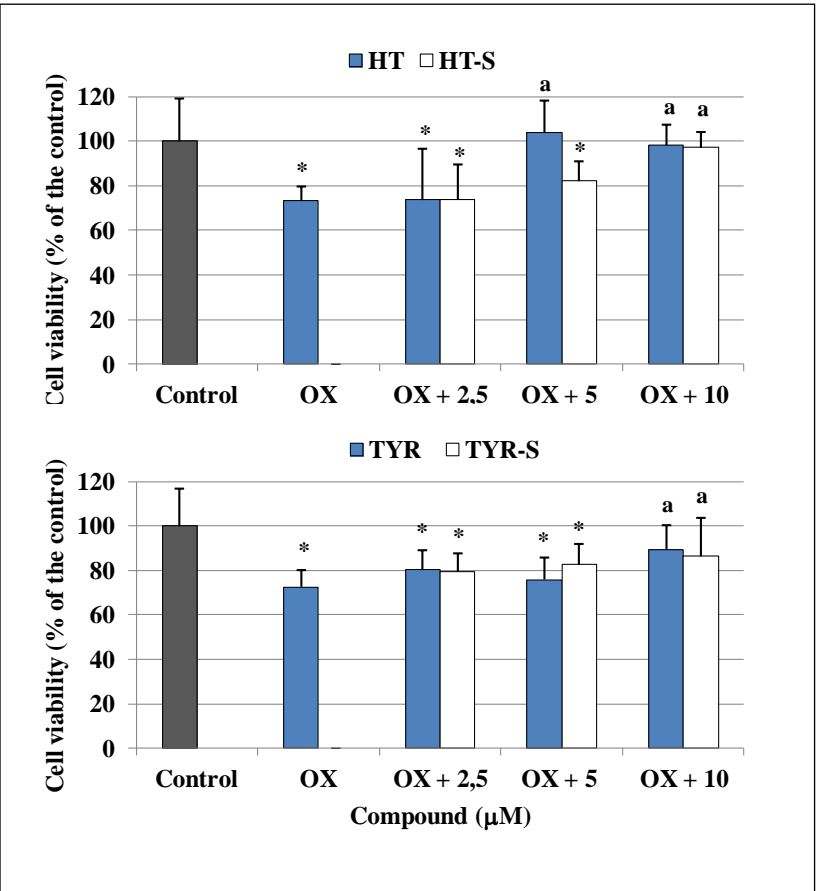

Fig.4 Cell viability measured in Caco-2 cells after $24 \mathrm{~h}$ incubation with $100 \mu \mathrm{g} / \mathrm{mL}$ oxidized cholesterol and pretreated (30 min) with TYR, HT or their sulfate metabolites $(2.5-10 \mu \mathrm{M}){ }^{*}=\mathrm{p}<0.05$ versus control, $\mathrm{a}=\mathrm{p}<0.05$ versus oxidized cholesterol treated $(\mathrm{Ox})$. 
B

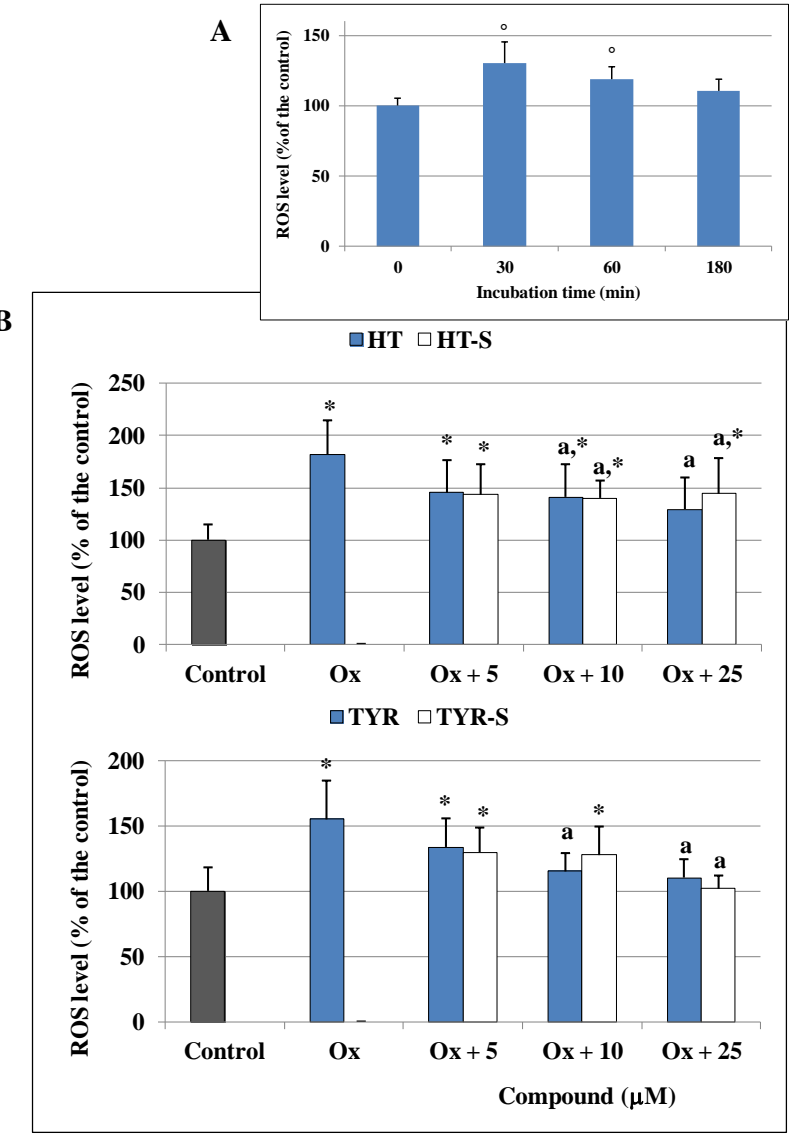

Fig.5 ROS level, expressed as \% of the control samples, in Caco- 2 cells, treated with $75 \mu \mathrm{g} / \mathrm{ml}$ oxidized cholesterol for different incubation times (5A) or pretreated (30 min) with TYR, HT or their sulfate metabolites $(5-25 \mu \mathrm{M})$ and treated with oxidized cholesterol for 30 min $(5 B)$, exposed to 2',7'dichlorodihydrofluorescein diacetate $\mathrm{H}_{2}$-DCF-DA $(10 \mathrm{mM})$ for $30 \mathrm{~min} .{ }^{*}=\mathrm{p}<0.05$ versus control, $\mathrm{a}=\mathrm{p}<0.05$ versus oxidized cholesterol treated $(\mathrm{Ox}),{ }^{\circ}=$ 25 $\mathrm{p}<0.05$ versus $0 \mathrm{~min}$

The oxidizing action of the mixture of oxidized cholesterol was then investigated monitoring the alteration of the cellular redox status with time: after $30 \mathrm{~min}$ of incubation a significant production of ROS was observed in the cells treated with the oxidized cholesterol in comparison with the control (Fig. 5A). Next, we measured ROS production at $30 \mathrm{~min}$, after pretreatment with the different phenolic 30 compounds $(5,10,25 \mu \mathrm{M})$. We observed that ROS production was significantly lower from the concentration of $10 \mu \mathrm{M}$ for all the tested compounds, except for TYR-S (Fig. 5B).

After 30 min of incubation with the oxidized cholesterol, ROS production was associated with a significant reduction of Caco-2 cellular GSH, around $40 \%$ of the initial value, as shown in Figure 6A. The level of GSH increased with time, reaching the control value at 3/6 h, to decrease again thereafter. Pretreatment with both HT and TYR preserved the control level of GSH at all the tested concentrations and 35 their sulfate metabolites exerted a comparable efficacy (Fig. 6B). Interestingly, none of the tested compounds was able to alter GSH level when incubated alone $(25 \mu \mathrm{M})$ in the experimental conditions used $(\mathrm{p}>0.5$ versus control).

With respect to the considered parameters, we did not observe any concentration dependent protective effect of the tested phenolic compounds, nor significant differences among parent compounds and metabolites. 
Cite this: DOI: $10.1039 / \mathrm{c0xx} 00000 \mathrm{x}$

www.rsc.org/xxxXXX

ARTICLE TYPE

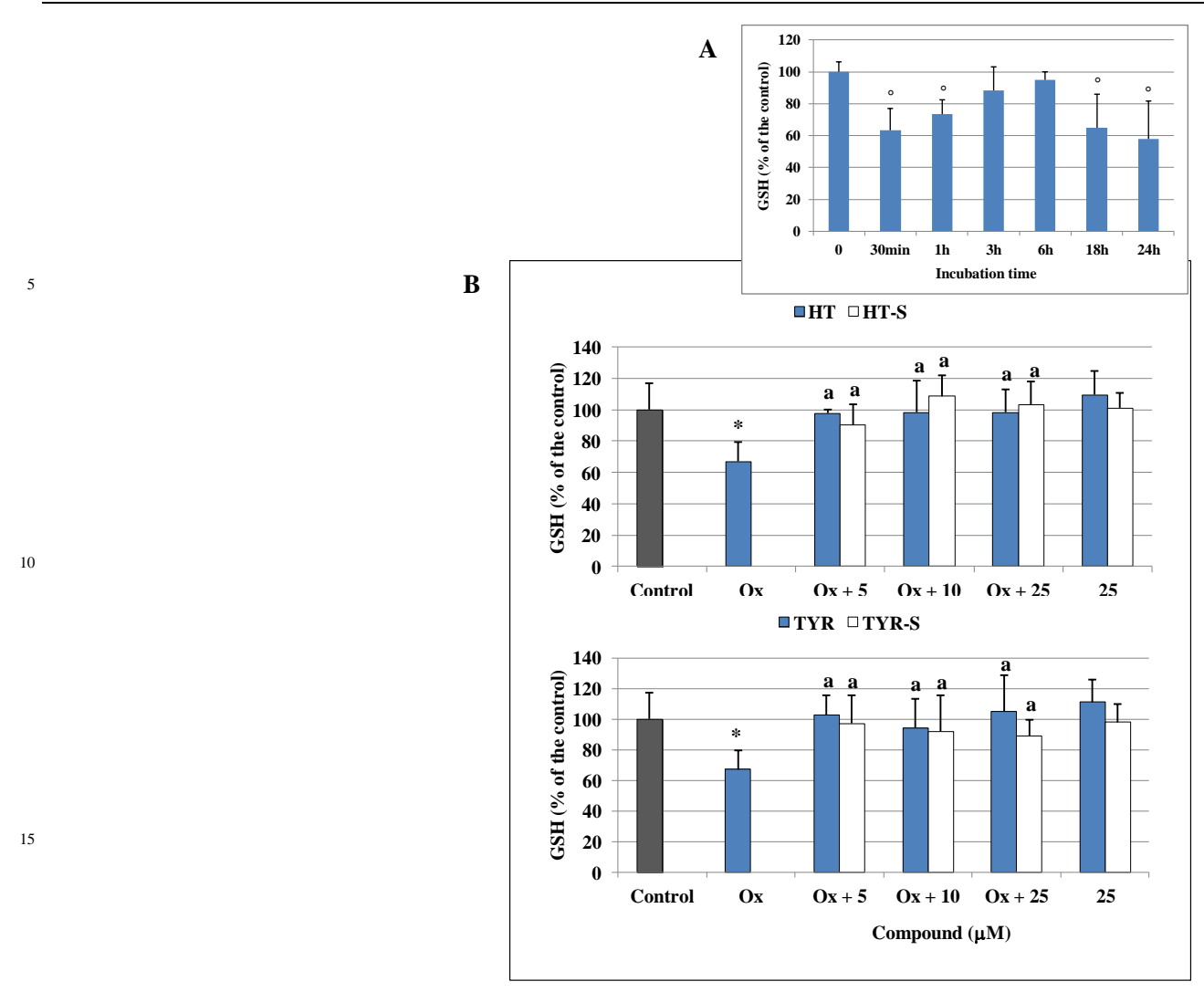

Fig.6 GSH level, expressed as \% of the control samples, in Caco-2 cells, treated with $75 \mu \mathrm{g} / \mathrm{mL}$ oxidized cholesterol for different incubation times (6A) or 20 pretreated $(30 \mathrm{~min})$ with TYR, HT or their sulfate metabolites $(5-25 \mu \mathrm{M})$ and treated with oxidized cholesterol for $30 \mathrm{~min}(6 \mathrm{~B}) . *=\mathrm{p}<0.05 \mathrm{versus}$ control, $\mathrm{a}=\mathrm{p}<0.05$ versus oxidized cholesterol treated $(\mathrm{Ox}),{ }^{\circ}=\mathrm{p}<0.05$ versus $0 \mathrm{~min}$

A significant increase of GPx activity, around 50\% above the control level, was also observed in Caco-2 cells treated with the oxidized cholesterol after $18 \mathrm{~h}$ of incubation (Fig. 7A). HT $(25 \mu \mathrm{M})$ induced an increase, although not significant, of the basal GPx activity; ${ }_{25}$ however, once incubated together with the oxidized cholesterol HT reduced the increase of the enzyme activity from $10 \mu \mathrm{M}$ with respect to the oxidized samples (Fig. 7B). HT sulphates $\mathbf{3}$ and $\mathbf{4}$ did not alter the control level but exerted the same activity of the parent compound for the oxidized samples.

In presence of TYR, GPx activity was significantly above the control level; a small effect was observed in pretreated samples with respect to the oxidized ones. In contrast, Caco- 2 cells pretreated with all tested concentrations of TYR sulphate $\mathbf{5}$ resulted in an enzyme 30 activity significantly lower with respect to the oxidized samples, and the enzyme basal activity was not influenced (Fig. 7B).

Finally, we evaluated the stability and uptake of HT, TYR and their sulfate metabolites from 30 min to $24 \mathrm{~h}$ of incubation in the Caco- 2 cultures. UPLC-MS analyses (see supporting information) revealed a partial loss of the compounds in the culture medium, very likely maybe due to the action of the fetal bovine serum present (MONICA, maybe it is non-specific binding to the fetal bovine serum?) or to the intrinsic stability to air oxidation of each compound, as can be deduced when comparing the negative controls of the compounds (no 35 eells) in medium and in lysis buffer (MONICA, that last sentence is only true with HT, but not with Tyr derivatives, so I'd rather try to be more speculative here giving two possible reasons (see above) and would avoid going deeper in explanations about controls by removing the crossed-out parts). Analysing supernatant medium and cell lysate fractions (MONICA, I corrected here since it was a bit confusing, since in the supp info tables we have called them "supernatants" to the lysates and "medium" to what here is called supernatant. I like the notation "supernatants" and "cell lysate fractions" better, so maybe the names in the supp info might be corrected

40 accordingly. As you wish) we observed that all the tested compounds entered the cells from 30 min of incubation and undergo an extensive metabolisation, giving rise to a pool of metabolites, among which we detected mainly sulfate and methyl-sulfate metabolites. 
5

A

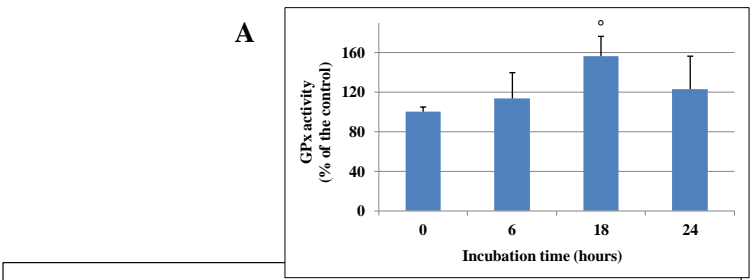

B
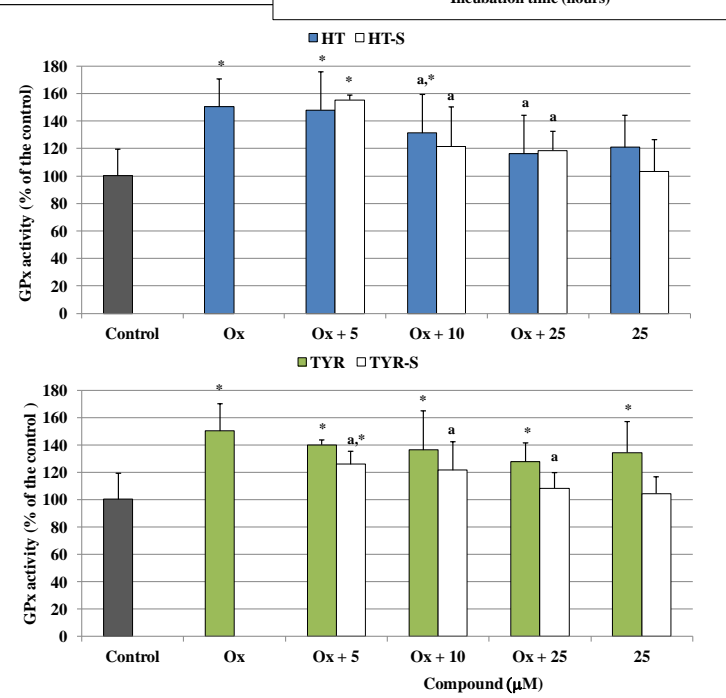

Fig.7 GPx activity, expressed as \% of the control samples, in Caco- 2 cells, treated with $75 \mu \mathrm{g} / \mathrm{mL}$ oxidized cholesterol for different incubation times (7A) or pretreated (30min) with TYR, HT or their sulfate metabolites $(5-25 \mu \mathrm{M})$ and treated with oxidized cholesterol for $18 \mathrm{~h}(7 \mathrm{~B}) . *=\mathrm{p}<0.05$ versus control, $\mathrm{a}=\mathrm{p}<0.05$ versus oxidized cholesterol treated $(\mathrm{Ox}),{ }^{\circ}=\mathrm{p}<0.05$ versus $0 \mathrm{~h}$ 


\section{Cite this: DOI: 10.1039/c0xx00000x}

\section{Discussion}

It is known that polyphenols undergo strong phase I and phase II metabolism, in which they are hydrolyzed (phase I) and later conjugated (phase II) into their glucuronidated, methylated and sulfated forms in order to be absorbed and excreted. Recently, such metabolites are 5 being taken into consideration to provide in vivo relevance for any activity.

Sulfate metabolites of phenolic compounds as resveratrol ${ }^{28} 29-30$, quercetin, epicatechin and catechin ${ }^{31-33}$, have been shown to exert a biological activity comparable to that of the parent compound. Quercetin-3-O-sulfate has been shown to retain an antioxidant effect, significantly inhibiting the $\mathrm{Cu}^{2+}$-induced oxidation of human $\mathrm{LDL}^{34}$. The free radical scavenging activity of a 3 -sulfate metabolite of resveratrol was comparable to that of the parent compound, when measuring the ability to quench the DPPH radical ${ }^{28}$.

10 In this work we have studied the potential protecting activity of HT and TYR sulfate metabolites in Caco-2 human endothelial intestinal cells where oxidative stress was provoked by oxidized cholesterol. Although the liver is the major organ for metabolism of many drugs and xenobiotics, the small intestine also contributes substantially to it by several pathways involving phase I and phase II reactions. At the same time, concentration of sulfate metabolites in the intestinal epithelium may be high, as glucuronidation and sulfation are major pathways of phase II xenobiotic metabolism in the human intestine ${ }^{12-13}$, and might contribute to preserve intestinal epithelium integrity 15 against pro-oxidant dietary agents.

We selected oxidized cholesterol for our oxidative stress cell model since cholesterol and its oxidation products have recently been shown to potentially interfere with the homeostasis of the intestinal epithelium ${ }^{18,20}$, due to their pro-oxidant and pro-inflammatory properties. Oxysterols are more polar and more readily diffusible through cell membranes, and have consistently been shown to be more reactive than unoxidized cholesterol, possessing marked pro-inflammatory and cytotoxic effects in a number of cells and tissues ${ }^{35-36}$. In 20 our oxidizing conditions, about $50 \%$ of the initial cholesterol was turned into oxidation products, mainly 7-ketocholesterol and some of the hydroxycholesterol isomers commonly found in cholesterol rich foodstuffs ${ }^{37}$. It has been reported that dietary cholesterol and some oxysterols of dietary origin are able to lead differentiated Caco-2 cells to both necrotic and apoptotic death, depending on the experimental conditions ${ }^{18,38-40}$.

In the present study, oxidized cholesterol toxic effects were investigated in terms of alteration of cellular redox state and oxidative 25 damage. Oxidized cholesterol exposure resulted in a significant production of ROS, in accordance with results reported by Biasi et al. ${ }^{18}$,

${ }^{41}$, being this likely the cause of oxidative damage and death. ROS production in Caco-2 cells treated with specific oxysterols has been reported to be due, at least in part, to the activation of NADPH oxidase ${ }^{18}$. In our experimental conditions ROS production was inversely correlated to a decrease of GSH level. GSH is the main non-enzymatic antioxidant defence within the cell, reducing different peroxides, hydroperoxides, and radicals (alkyl, alkoxyl, peroxyl, etc.). It is usually assumed that GSH depletion reflects intracellular oxidation 30 whereas an increase in GSH concentration could be expected to prepare the cell against a potential oxidative insult ${ }^{42-43}$.

In our oxidative stress model, in cells pretreated with HT, we observed an inhibition in the formation of ROS and also prevention of GSH level decrease. HT protective effect could predominantly be attributed to the capacity of acting as free radical scavenger, as already documented in the same cells treated with other oxidizing agents, $\mathrm{TBH}^{8}$ and acrylamide ${ }^{44}$. The well known free radical scavenging and metal chelating activities are mostly due to HT ortho-diphenolic structure, whose high antioxidant activity may be explained by the high 35 electron donating effect of the second hydroxyl group.

Despite the lack of the catechol group in their structure, HT sulfate metabolites (3-4) were as effective as HT itself. It is interesting to note however that, as shown by our uptake studies (see supporting information), both HT and its sulfate metabolite enter the cells and are partially converted one into the other, thus what we observe is in part the resultant of the activity of both compounds.

At the same time, TYR and its sulfate metabolite $\mathbf{5}$ display very similar protecting ability against oxidation in our cell model, and TYR

40 possesses only one $\mathrm{OH}$ phenolic group whereas TYR sulfate does not has any hydroxyl substituent in its aromatic ring. In the case of TYR, it has been shown to have scavenging effects on $\mathrm{ONOO}^{-45}, \mathrm{O}_{2}^{-46}$ and peroxyl radicals ${ }^{8}$.

It is important to remark that, in addition to the antioxidant capacity of natural polyphenols by directly scavenging extracellular/intracellular ROS, several phenolic compounds have been shown to provide a parallel protection by enhancing the level of GSH and the activity of a number of related protective enzymes ${ }^{47}$. Among these enzymes, GPx catalyses the reduction of peroxides and 45 is suggested to act as barrier against hydroperoxide attack ${ }^{48}$. In our experimental conditions, none of the tested compounds altered the basal level of GSH, but TYR was able to significantly increase the activity of GPx after $18 \mathrm{~h}$ of incubation. At that time point, in Caco- 2 cells exposed to the oxidized cholesterol we detected a significant increase of the GPx activity, indicating a positive response of the cell defence system to face an oxidative insult ${ }^{42-43}$. Thus, pre-treatment with HT and HT sulfates prevented the increase in the activity of GPx induced by oxidative stress, either by direct action on the enzyme activity or via the decrease in (decreasement/ decreasing of) ROS 50 production and consequently in cell damaging peroxide species.

The same result was found in presence of TYR sulfate metabolite. GPx activity in Caco-2 cells was significantly enhanced with respect 
to the control in all samples pretreated with TYR, in presence or not of oxidized cholesterol. This outcome is the first evidence of an inductive effect on GPx activity of TYR, which has been shown to preserve GSH level under oxidative stress conditions without altering GPx basal level in Caco-2 ${ }^{49}$ and macrophage-like (J774 A1) ${ }^{50}$ cell lines. Our data are in agreement with that previously published with HT in HepG2 ${ }^{43,51}$ and in Caco-2 ${ }^{44}$ cells. Similarly, flavanols, such as epicatechin-3-gallate and procyanidin B2, induce a significant 5 increase in several antioxidant-related enzymes activities, accompanied by a decrease in ROS production not affecting GSH content in Caco- 2 cells ${ }^{52}$.

When Caco-2 cells were treated with oxidized cholesterol for $24 \mathrm{~h}$, a significant increase of MDA production was observed, together with a decrease in cell viability, indicating a lipo-peroxidative injury to the cell. Pretreatment with all the phenolic compounds and the corresponding sulfate metabolites inhibited MDA formation at all tested concentrations. At $24 \mathrm{~h}$ of incubation, regardless the phenolic 10 compound initially present in the incubation mixture (parent compound or sulfate metabolite), we found a pool of compounds (see supporting information), mainly sulfate and methyl-sulfate metabolites, in agreement with Rubio et al. ${ }^{13}$, due to the intense metabolising activity of Caco-2 cells, all of which probably contribute to the final effect.

None of the compounds however was equally efficient in preventing cell death. This result suggests that the alteration of cellular redox status did not led only to a direct oxidative injury, but likely modulated signalling pathways involved in cell survival, as demonstrated in 15 differentiated Caco-2 cells, where both unoxidized cholesterol and (as well as) an oxysterol mixture were able to induce apoptosis as a consequence of enhanced ROS production ${ }^{18}$.

The actual contribution of phenolic metabolites to the biological activity of the parent compounds is still quite controversial. In fact, Khymenets et al. ${ }^{53}$ reported the lack of antioxidant activity for HT glucuronate metabolites compared with that of the parent compounds, suggesting that they were not chief contributors that explain (to) the antioxidant effects provided by olive oil consumption. In contrast, ${ }_{20}$ Paiva-Martins et al. ${ }^{15}$ recently described the protective effects of HT glucuronides on erythrocyte oxidative-induced hemolysis to a similar extent to that observed for HT itself. These results suggested that HT metabolites may play an important role in the protective activity of olive oil phenolic compounds.

\section{Conclusions}

In conclusion, our data provides evidence of the ability of sulfate metabolites of HT and TYR to protect intestinal cells against the pro25 oxidant effect of oxidized cholesterol, with an efficiency comparable to that of the parent compounds, strengthening the assumption that the potential beneficial effect of the parent compounds is retained, if not enhanced, although extensive metabolisation occurs, being the resulting metabolites able to exert a biological action themselves. Sulfate metabolites may be present in the intestinal epithelium, as the result of deconjugation/conjugation processes; thus, they may significantly contribute to the protective activity exerted by olive oil simple phenols against the oxidation process triggered by lipid peroxides on the intestinal mucosa.

30 


$\begin{array}{ll}\text { Abbreviations } & \\ \text { HT } & \text { hydroxytyrosol } \\ \text { TYR } & \text { tyrosol } \\ \text { 5 HT-S } & \text { HT sulfate metabolites 3-4 } \\ \text { TYR-S } & \text { TYR sulfate metabolite 5 } \\ \text { MDA } & \text { malonyldialdehyde } \\ \text { NR } & \text { neutral red } \\ \text { ROS } & \text { reactive oxygen species } \\ \text { 10 GSH } & \text { glutathione } \\ \text { GPx } & \text { glutathione peroxidase }\end{array}$

\section{Acknowledgements}

We gratefully acknowledge financial support from the Regione Autonoma della Sardegna (LR7- CRP-25300), Fondazione Banco di ${ }_{15}$ Sardegna and Junta de Andalucía (CVI-5007).

${ }^{a}$ Dipartimento di Scienze Biomediche, Unità di Patologia Sperimentale, Università degli Studi di Cagliari, Cittadella Universitaria SS 554, 09042 Monserrato, Cagliari, Italy. Fax: 39070 6754032; Tel: +39070 6754126; E-mail: mdeiana@unica.it

$20{ }^{b}$ Department of Bioorganic Chemistry, Instituto de Investigaciones Quimicas, CSIC-Universidad de Sevilla, 49 Americo Vespucio, 41092 Sevilla, Spain. Fax: +34 95 8181632; Tel: +34958181644; E-mail: jcmorales@iiq.csic.es

${ }^{c}$ Institute of Parasitology and Biomedicine López Neyra, Avenida del Conocimiento, 17, 18016 Armilla-Granada, Spain

${ }^{d}$ Department of Analytical Chemistry, Faculty of Sciences, University of Granada, C/Severo Ochoa, s/n, 18001 Granada, Spain

${ }^{e}$ Dipartimento di Medicina Molecolare, Università degli Studi di Pavia, Via Ferrata 9, 27100 Pavia, Italy

25

$\dagger$ Electronic Supplementary Information (ESI) available: [1H-NMR and 13C-NMR spectra of compounds 3-4, 5,7, 9-10, 11-12 and TYR, HT and sulfate metabolites stability/uptake in Caco-2 cultures]. See DOI: 10.1039/b000000x/

\section{${ }_{30}$ References}

1. S. Martin-Pelaez, M. I. Covas, M. Fito, A. Kusar and I. Pravst, Mol Nutr Food Res, 2013, 57, 760-771.

2. F. Visioli and E. Bernardini, Curr Pharm Des, 2011, 17, 786-804.

3. M. N. Vissers, P. L. Zock, A. J. Roodenburg, R. Leenen and M. B. Katan, J Nutr, 2002, 132, 409-417.

4. L. Rubio, R. M. Valls, A. Macia, A. Pedret, M. Giralt, M. P. Romero, R. de la Torre, M. I. Covas, R. Sola and M. J. Motilva, Food Chem, 2012, 135, $35 \quad 2922-2929$.

5. J. Pinto, F. Paiva-Martins, G. Corona, E. S. Debnam, M. Jose Oruna-Concha, D. Vauzour, M. H. Gordon and J. P. Spencer, Br J Nutr, 2011, 105, 16071618.

6. M. de Bock, E. B. Thorstensen, J. G. Derraik, H. V. Henderson, P. L. Hofman and W. S. Cutfield, Mol Nutr Food Res, 2013, 57, $2079-2085$.

7. G. Corona, X. Tzounis, M. A. Dessi, M. Deiana, E. S. Debnam, F. Visioli and J. P. E. Spencer, Free Radic Res, 2006, 40, 647-658.

40 8. M. Deiana, G. Corona, A. Incani, D. Loru, A. Rosa, A. Atzeri, M.P. Melis and M. A. Dessi, Food Chem Toxicol, 2010, 48, 3008-3016.

9. R. de la Torre, Inflammopharmacology, 2008, 16, 245-247.

10. E. Miro-Casas, M. I. Covas, M. Farre, M. Fito, J. Ortuno, T. Weinbrenner, P. Roset and R. de la Torre, Clin Chem, $2003,49,945-952$.

11. K. L. Tuck, P. J. Hayball and I. Stupans, J Agric Food Chem, 2002, 50, 2404-2409.

12. J. H. Lin, M. Chiba and T. A. Baillie, Pharmacol Rev, 1999, 51, 135-158.

45 13. L. Rubio, A. Macia, A. Castell-Auvi, M. Pinent, M. T. Blay, A. Ardevol, M. P. Romero and M. J. Motilva, Food Chem, $2014,149,277-284$.

14. M. Deiana, A. Incani, A. Rosa, A. Atzeri, D. Loru, B. Cabboi, M.P. Melis, R. Lucas, J. C. Morales and M.A. Dessi, Chem Biol Interact, 2011, 193, 232-239.

15. F. Paiva-Martins, A. Silva, V. Almeida, M. Carvalheira, C. Serra, J. E. Rodrigues-Borges, J. Fernandes, L. Belo and A. Santos-Silva, J Agric Food Chem, 2013, 61, 6636-6642. 
16. M. Pinto, S. Robine-Leon, M.-D. Appay, M. Kedinger, N. Triadou, E. Dussaulxs, B. Lacrox, P. Simon-Assmann, K. Haffen, J. Fogh and A. Zweibaum, Biol Cell, 1983, 47, 323-330.

17. Q. Li, Y. Sai, Y. Kato, I. Tamai and A. Tsuji, Pharmacol Res, 2003, 20, 1119-1124.

18. F. Biasi, C. Mascia, M. Astegiano, E. Chiarpotto, M. Nano, B. Vizio, G. Leonarduzzi and G. Poli, Free Radic Biol Med, $2009,47,1731-1741$.

5 19. F. Biasi, C. Mascia and G. Poli, Carcinogenesis, 2008, 29, 890-894.

20. C. Mascia, M. Maina, E. Chiarpotto, G. Leonarduzzi, G. Poli and F. Biasi, Free Radic Biol Med, 2010, 49, $2049-2057$.

21. A. Rosa, M. Deiana, A. Atzeri, G. Corona, A. Incani, M. P. Melis, G. Appendino and M. A. Dessi, Chem Biol Interact, 2007, 165, 117-126.

22. M. Calderon-Santiago, A. Peralbo-Molina, F. Priego-Capote and M. D. L. de Castro, Eur J Lipid Sci Tech, 2012, 114, 687-694.

23. S. Grasso, L. Siracusa, C. Spatafora, M. Renis and C. Tringali, Bioorg Chem, 2007, 35, 137-152.

10 24. R. Lucas, F. Comelles, D. Alcantara, O. S. Maldonado, M. Curcuroze, J. L. Parra and J. C. Morales, J Agric Food Chem, $2010,58,8021-8026$.

25. R. Fautz, B. Husein and C. Hechenberger, Mutat Res, 1991, 253, 173-179.

26. J. Templar, S. P. Kon, T. P. Milligan, D. J. Newman and M. J. Raftery, Nephrol Dial Transplant, 1999, 14, 946-951.

27. S. Dinicola, M. A. Mariggio, C. Morabito, S. Guarnieri, A. Cucina, A. Pasqualato, F. D'Anselmi, S. Proietti, P. Coluccia and M. Bizzarri, Br J Nutr, 2013, 110, 797-809.

15 28. J. Hoshino, E. J. Park, T. P. Kondratyuk, L. Marler, J. M. Pezzuto, R. B. van Breemen, S. Mo, Y. Li and M. Cushman, J Med Chem, 2010, 53, 50335043.

29. V. Aires, E. Limagne, A. K. Cotte, N. Latruffe, F. Ghiringhelli and D. Delmas, Mol Nutr Food Res, 2013, 57, 1170-1181.

30. R. Ruotolo, L. Calani, E. Fietta, F. Brighenti, A. Crozier, C. Meda, A. Maggi, S. Ottonello and D. Del Rio, Nutr Metab Cardiovasc Dis, 2013, 23, 1086-1092.

20 31. J. Terao, J Med Invest, 1999, 46, 159-168.

32. T. Koga and M. Meydani, Am J Clin Nutr, 2001, 73, 941-948.

33. S. Tribolo, F. Lodi, C. Connor, S. Suri, V. G. Wilson, M. A. Taylor, P. W. Needs, P. A. Kroon and D. A. Hughes, Atherosclerosis, 2008, $197,50-56$.

34. C. Manach, C. Morand, V. Crespy, C. Demigne, O. Texier, F. Regerat and C. Remesy, FEBS Lett, 1998, 426, 331-336.

35. A. Vejux, L. Malvitte and G. Lizard, Braz J Med Biol Res, 2008, 41, 545-556.

25 36. G. Leonarduzzi, P. Gamba, S. Gargiulo, B. Sottero, A. Kadl, F. Biasi, E. Chiarpotto, N. Leitinger, G. Vendemiale, G. Serviddio and G. Poli, Aging Cell, 2008, 7, 375-382.

37. J. Plat, J. A. Nichols and R. P. Mensink, J Lipid Res, 2005, 46, 2468-2476.

38. A. J. O'Sullivan, Y. C. O'Callaghan, J. A. Woods and N. M. O'Brien, J Appl Toxicol, 2003, 23, 191-197.

39. E. Ryan, J. Chopra, F. McCarthy, A. R. Maguire and N. M. O'Brien, Br J Nutr, 2005, 94, 443-451.

30 40. S. Roussi, A. Winter, F. Gosse, D. Werner, X. Zhang, E. Marchioni, P. Geoffroy, M. Miesch and F. Raul, Cell Death Differ, $2005,12,128-135$.

41. F. Biasi, T. Guina, M. Maina, B. Cabboi, M. Deiana, C. I. Tuberoso, S. Calfapietra, E. Chiarpotto, B. Sottero, P. Gamba, S. Gargiulo, V. Brunetto, G. Testa, M. A. Dessi, G. Poli and G. Leonarduzzi, Biochem Pharmacol, 2013, 86, 138-145.

42. M. Alia, R. Mateos, S. Ramos, E. Lecumberri, L. Bravo and L. Goya, Eur J Nutr, 2006, 45, 19-28.

43. L. Goya, R. Mateos and L. Bravo, Eur J Nutr, 2007, 46, 70-78.

35 44. I. Rodriguez-Ramiro, M. A. Martin, S. Ramos, L. Bravo and L. Goya, Toxicology, 2011, 288, 43-48.

45. R. de la Puerta, M. E. Martinez Dominguez, V. Ruiz-Gutierrez, J. A. Flavill and J. R. Hoult, Life Sci, 2001, 69, 1213-1222.

46. A. A. Bertelli, M. Migliori, V. Panichi, B. Longoni, N. Origlia, A. Ferretti, M. G. Cuttano and L. Giovannini, Ann NY Acad Sci, $2002,957,295-301$.

47. R. Masella, R. Di Benedetto, R. Vari, C. Filesi and C. Giovannini, J Nutr Biochem, 2005, 16, 577-586.

48. X. G. Lei, W. H. Cheng and J. P. McClung, Annu Rev Nutr, 2007, 27, 41-61.

40 49. C. Giovannini, E. Straface, D. Modesti, E. Coni, A. Cantafora, M. De Vincenzi, W. Malorni and R. Masella, J Nutr, 1999, $129,1269-1277$.

50. R. Di Benedetto, R. Vari, B. Scazzocchio, C. Filesi, C. Santangelo, C. Giovannini, P. Matarrese, M. D'Archivio and R. Masella, Nutr Metab Cardiovasc Dis, 2007, 17, 535-545.

51. M. A. Martin, S. Ramos, A. B. Granado-Serrano, I. Rodriguez-Ramiro, M. Trujillo, L. Bravo and L. Goya, Mol Nutr Food Res, $2010,54,956-966$.

52. I. Rodriguez-Ramiro, M. A. Martin, S. Ramos, L. Bravo and L. Goya, Eur J Nutr, 2011, 50, 313-322.

45 53. O. Khymenets, M. Fito, S. Tourino, D. Munoz-Aguayo, M. Pujadas, J. L. Torres, J. Joglar, M. Farre, M. I. Covas and R. de la Torre, Drug Metab Dispos, 2010, 38, 1417-1421. 